\title{
Correction to: Tocilizumab: A Review in Rheumatoid Arthritis
}

\author{
Lesley J. Scott ${ }^{1}$
}

Published online: 19 December 2017

(C) Springer International Publishing AG, part of Springer Nature 2017

\section{Correction to: Drugs https://doi.org/10.1007/s40265- 017-0829-7}

The article Tocilizumab: A Review in Rheumatoid Arthritis, written by Lesley J. Scott, was originally published Online First without open access. After publication in volume 77, issue 17, pages 1865-1879 F. Hoffmann-La Roche Ltd requested that the article be Open Choice to make the article an open access publication. Post-publication open access was funded by F. Hoffmann-La Roche Ltd. Further details may be found at http://www. medengine.com/Redeem/68FBF06068F81EA7. The article is forthwith distributed under the terms of the Creative Commons Attribution-NonCommercial 4.0 International License (http://creativecommons.org/licenses/bync/4.0/), which permits any noncommercial use, duplication, adaptation, distribution and reproduction in any medium or format, as long as you give appropriate credit to the original author(s) and the source, provide a link to the Creative Commons license and indicate if changes were made.
The original article can be found online at https://doi.org/10.1007/ s40265-017-0829-7.

Lesley J. Scott

demail@springer.com

1 Springer, Private Bag 65901, Mairangi Bay, Auckland 0754, New Zealand 